\author{
MARTIN HLOŽEK
}

\title{
HORIZONTAL CHANNEL DEVELOPMENT ON THE UPPER JIZERA AND THE UPPER VLTAVA RIVERS BETWEEN 1938 AND 2012
}

\begin{abstract}
HLOŽEK, M. (2014): Horizontal channel development on the upper Jizera and the upper Vltava Rivers between 1938 and 2012. Geografie, 119, No. 2, pp. 105-125. Through the use of orthophotomaps from 1938 and 1952, this paper examines the development of horizontal channels of selected rivers in mountain areas of the Bohemian Massif. Two study sites in northern and southern part of Bohemian Massif were analysed in order to evaluate changes in river channels under similar natural conditions. Developments on the Upper Jizera River and its tributary, the Jizerka River, were investigated for the time period of 1938-2012. The Upper Vltava (Moldau) river, along with its tributaries, was studied in regards to developments taking place over the period of 1952-2012. Historical orthophotomaps were georeferenced and river banks were subsequently determined through the use of ArcGIS software. Both sites are situated in wide valleys with a low gradient, representing an exceptional relief in generally mountainous regions. Channel changes are documented via fluvial lakes, paleomeander remnants and meander cut-offs. Together with high precipitation rates in both basins, periods of extreme floodings seem to have a significant influence on channel development and transformation. Lateral erosion is somewhat less intense when compared to other rivers in similar natural environments across Central Europe. The estimated maximum lateral erosion in the Upper Jizera River basin is 0.5 m.year ${ }^{-1}$, whereas in the Vltava River basin, the lateral erosion reaches up to $1.1 \mathrm{~m}$. year $^{-1}$.

KEY WORDS: horizontal channel change - fluvial processes - the Jizera River - the Vltava River.
\end{abstract}

\section{Introduction}

Active meandering rivers belong to the most dynamic parts of the relief. The mechanisms, timescale and variability of the channel change have been studied intensively in the last decades. However, these segments of fluvial system still remain to be fully understood. Studying historical channel changes represents an important basis for predicting ongoing fluvial processes and provides the key to understanding the evolution of the relief. Channel change research is not applicable only in fluvial geomorphology. It is also useful in terms of habitat management and impact on anthropogenic activities (Hooke 2007). The analysis and assessment of river channel change has been successively developed especially with GIS tools since the last decade of the $20^{\text {th }}$ century. In addition, GIS tools provide better possibilities to quantify errors, which affect the precision of analytical results (Gurnell, Downward, Jones 1994). The introduction to GIS possibilities for assessing channel change was published by Gurnell, Downward, Jones (1994) and Gurnell (1997). Many studies were concerned with 
channel changes in prevailing natural conditions (e.g. Hooke 1995; Warburton, Danks, Wishart 2002; Hooke 2007; Wolfert, Maas 2007) or with fluvial systems undergoing a significant anthropogenic activity (e.g. Surian, Rinaldi 2003; Pišút 2006; Li, Lu, Chen 2007). Some investigations focused on the configuration of flow processes and changes in bars (e.g. Luchi et al. 2010; Frothingham, Rhoads 2003). Other investigations proposed hydrodynamic models simulating the development of river meanders (e.g. Duan, Julien 2010; Dulal, Shimizu 2010). Considerable number of studies is concerned with the impact of floods on channel change (e.g. Lehotský, Novotný, Szmanda 2010; Fuller 2008). The effect of large woody debris and riparian vegetation on channel morphology was examined (e.g. Kail 2003; Brooks, Brierley, Millar 2003; Andreoli, Comiti, Lenzi 2007) as well as the effect of thermoabrasion (e.g. McEwen, Matthews 1998; Kasprzak, Traczyk 2011).

The influence of the floods as the crucial factors on the stability of the river banks and the consequent channel change is widely discussed in literature. The important question is concerned with frequency and magnitude at which the flood begins to erode the river banks effectively. Wolman and Miler (1960) suggest that largest amount of erosional activity is provided by discharge occurring once or twice in two years. Thus, large percentage of erosion is performed by relatively frequent flood events with rather low magnitudes. Consequently, low frequency of high magnitude floods causes relatively insignificant amount of eroded sediment within a long period (e.g. Scott, Gravlee 1968). However, the mentioned relation is complex as the channel forming discharge evidently depends on bank cohesiveness (e.g. Thorne 1991) and the geological, geomorphological, pedological and vegetational settings of particular basin (e.g. Magilligan 1992). This task is thus still really difficult to describe in general terms.

In Czechia, there are not many publications investigating horizontal changes of river channels. A comprehensive geographical analysis of historical maps and orthophotographs together with terrain mapping were usual methods in each study. The channel changes were studied on the Sviňovický potok Brook after its revitalisation (Kliment et al. 2008). For the analysis of fluvial dynamics were in addition used aerial photographs taken from a low-flying model aeroplane and a helicopter. River cross sections were obtained from the total station. Anthropogenically induced river network shortening was examined in the Otava River basin over the last 150 years (Langhammer, Vajskebr 2007; Langhammer, Vilímek 2008). Langhammer and Matoušková (2006) investigated anthropogenic modifications of river network in the Blanice River basin. Kasprzak and Traczyk (2011) studied channel changes on the Upper Jizera River and the Jagnięcy potok Brook, Poland, for period of 1953-2007. The authors attempted to retrieve the impact of extreme flood episodes and thermoabrasion on fluvial dynamics. Several Master theses concerning channel changes have been published as well. Oprchal (2009) investigated the Svratka River channel change, Skalická (2008) studied the Tichá Orlice River and Trnčák (2012) examined the channel development on the Morávka River.

The channel change studies are limited due to the period for which the aerial photographs are available. In former Czechoslovakia, the first aerial photographs with high accuracy appeared in 1936-1938, provided by the Czechoslovak army (Pavelková Chmelová, Netopil 2007). State-wide aerial imaging was 
interrupted during the World War II and then re-established again in 1946. The second period of state-wide imaging was taking place during 1952-1957. Thus, the recent changes occurring over the last few decades can be observed.

The main aim of this paper is to examine the evidence of the horizontal channel changes on the Upper Jizera and Upper Vltava Rivers and their tributaries which occurred over a medium-term period of 60 and 74 years respectively, based on the analysis of the information from the sets of aerial photographs in GIS environment. The selected rivers meander in environments insignificantly influenced by anthropogenic factors and thus represent the recent natural development of fluvial systems within Central Europe. It is supposed, that for the Upper Jizera River basin will lateral erosion reach the rates around 0.5 m.year ${ }^{-1}$, as presented in Kasprzak and Traczyk (2011). For the Upper Vltava River basin the lateral erosion rates will be characterised by analogous rates.

\section{Study Sites}

The two selected sites are located in the mountain relief; nevertheless, geomorphological conditions of the Upper Jizera and Upper Vltava River with wide low gradient valleys are rather exceptional in mountain regions. The selected rivers are characterised by prevailing meanders or bends with dominant lateral erosion. Slip-off slopes with point bars and river-cut cliffs with bank scours are significant in the meandering river reaches. The channel cross section is generally distinguished by an asymmetry. As a result of lateral migration of the meanders, fluvial lakes are developed in selected basins. On the other hand, some reaches are rather influenced by the river incision and straight direction (parts of reaches Jizera 3, 4, Jizerka 3 and Vltava, see Fig. 1 and 2). Moreover, both the basins have undergone insignificant changes led by anthropogenic processes.

\subsection{The Upper Jizera River basin}

The Upper Jizera River and its right tributary, the Jizerka River, are situated on a summit plateau of the Jizerské hory Mts. in northern Bohemia (Fig. 1). This basin belongs to the western part of the Sudetes mountain system. Altogether, the river reaches approximately $22 \mathrm{~km}$ long were studied (14 km on the Jizera River, $8 \mathrm{~km}$ on the Jizerka River). The main part of the Upper Jizera River flows along the Czech-Polish border. The Jizera River source is situated at 1,058 $\mathrm{m}$ a.s.l. on the southern slope of Smrk Mountain (1,124 m; Pilous 2008), the drainage area before the junction of the Jizerka River is $46.8 \mathrm{~km}^{2}$. Unfortunately, the discharge characteristics are not monitored on the Upper Jizera River. The nearest hydrological profile is located in Jablonec nad Jizerou, characterised by the annual discharge of $5.70 \mathrm{~m}^{3} \cdot \mathrm{s}^{-1}$ (ČHMÚ 2014). The Jizerka River originates at $900 \mathrm{~m}$ a.s.l. on the southern slope of Český vrch Hill and the drainage area aggregates $13.3 \mathrm{~km}^{2}$ (Tesař, Paczos 2009) and annual discharge amounts to $0.4 \mathrm{~m}^{3} \cdot \mathrm{s}^{-1}$ (MŽP ČR 2010). The river gradients are $20.6 \%$ for the Jizera River to the Jizerka River junction and 19\%o for the 


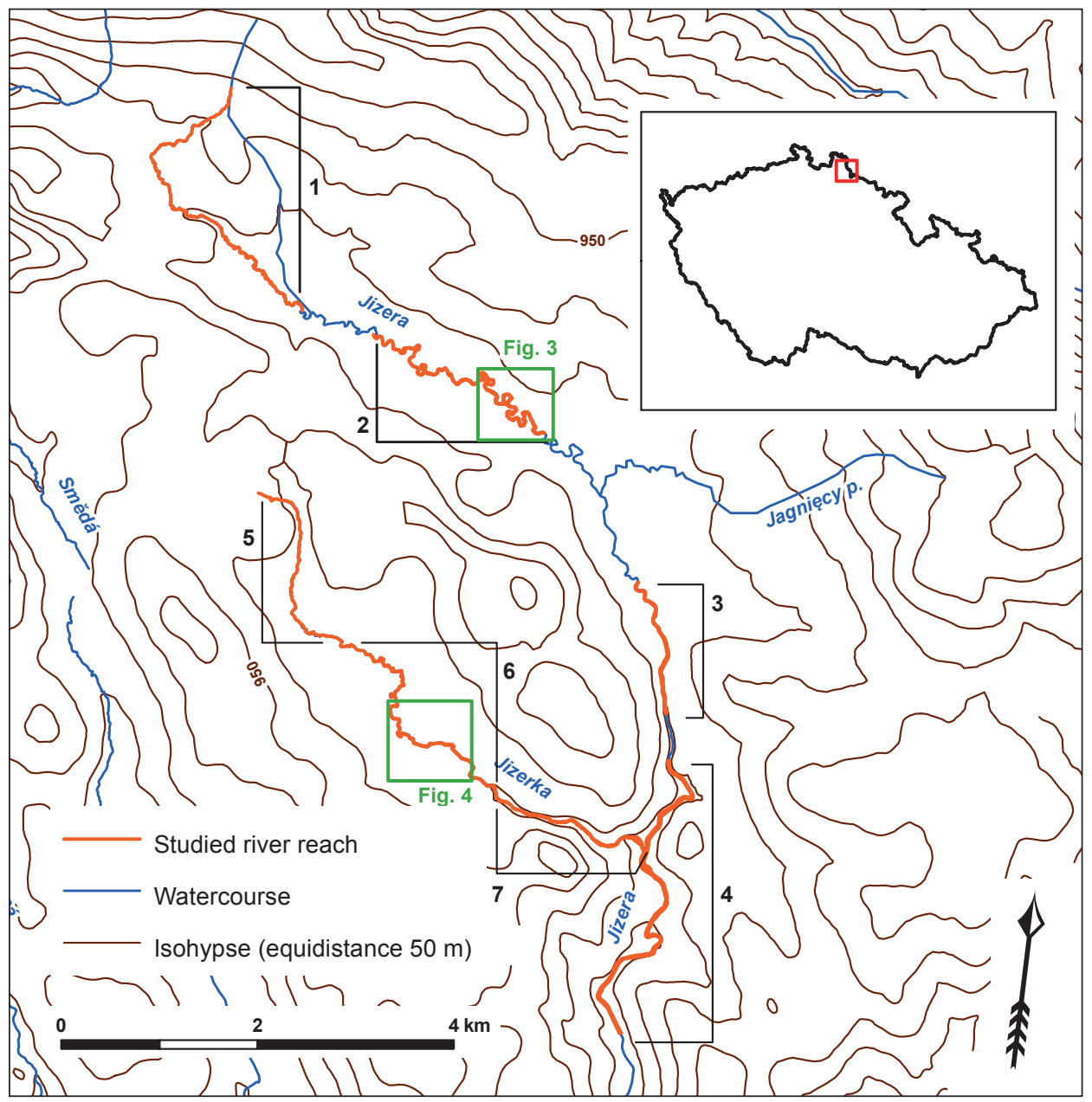

Fig. 1 - Study site in the Upper Jizera River basin. 1-4 - Jizera 1-4 reaches, 5-7 - Jizerka 1-3 reaches. Data for the Studená Vltava: after Czech Hydrometeorological Institute (2014), data for the Jizera River: Štekl et al. (2001), Vrabec et al. (2000), Daňhelka et al. (2006).

Jizerka River. The river reaches were investigated within the altitude interval of 935-729 $\mathrm{m}$ a.s.l. The selected basin appertains to cold climatic regions CH4 and CH6 according to Quitt's classification (1971) with the mean annual air temperature between 4 and $5{ }^{\circ} \mathrm{C}$ (Tolasz et al. 2007). The mean annual precipitation exceeds $1,200 \mathrm{~mm}$, with the highest values recorded in Jizerka village (Bubeníčková, Kulasová 2009; Tolasz et al. 2007). However, a regional distribution of precipitation strongly depends on microclimatic characteristics of the individual drainage area and its exposition towards precipitation.

The floodplain mostly consists of unconsolidated fluvial and organic sediments, lying on Palaeozoic granite bedrock (Chaloupský 1988, 1989). A large peat bog area stretching along the cited reaches is protected under National Nature Reserve Rašeliniště Jizery a Jizerky peat bogs. Moreover, this locality 
Tab. 1 - List of the floods with minimum 5-year recurrence on the Upper Jizera River (in Jablonec nad Jizerou) and the Studená Vltava River (in Černý Kř́íž)

\begin{tabular}{|ll|l|}
\hline The Studená Vltava River & The Jizera River \\
\hline 24 December 1967 & 30 December 2002 & 25 August $1938^{1}$ \\
20 November 1971 & 3 January 2003 & 29 May $1941^{1}$ \\
29 December 1974 & 13 January 2004 & 14 August $1948^{1}$ \\
21 December 1993 & 28 May 2006 & 1 August $1977^{1}$ \\
1 November 1998 & 1 March 2007 & August $1978^{1}$ \\
23 March 2001 & 7 December 2007 & July $1997^{1}$ \\
21 March 2002 & 1 March 2008 & 10 March $2000^{2}$ \\
12 August 2002 & 18 April 2009 & August $2006^{3}$ \\
\hline
\end{tabular}

${ }^{1}$ Štekl et al. (2001), ${ }^{2}$ Vrabec, Elleder, Kessl (2000), ${ }^{3}$ Daňhelka et al. (2006)

was registered as the Horní Jizera Ramsar site (Vršovský 2013). On the meandering reaches (numbers 3 and 6 in Figure 1), the riparian vegetation mostly consists of anthropogenically unaffected peat bogs or meadows eventually. The banks of the remaining reaches are covered by extensively used coniferous forest and meadows. The runoff regime variability is affected by windward effects in the Jizerské hory Mts. causing significant channel forming discharges especially during summer. The less considerable flood period occurs during thawing of large snow amounts in winter or spring (Povodí Labe 2009). The evidence of the predominating summer floods of higher magnitude for the period of 1938-2012 is shown in Table 1 . The most significant floods were reported in August 1977, 1978 and August 2002. In 1978, $186 \mathrm{~mm}$ of diurnal precipitation occurred in Jizerka village. In 2002 , total precipitation amount exceeded $280 \mathrm{~mm}$ in one day in the same locality (Bubeníčková, Kulasová 2009).

\subsection{The Upper Vltava River basin}

The study site is situated in the eastern part of the Šumava Mountains, the south-western part of the Bohemian Massif (Fig. 2). Total length of the examined river reaches amounts to approximately $30 \mathrm{~km}$. The Studená Vltava River originates at the junction of the Goldgrubenbach Brook and the Rothbach Brook, Germany. The total length of the Studená Vltava River is $24 \mathrm{~km}$, the mean discharge at the junction with the Teplá Vltava River $2.2 \mathrm{~m}^{3} \cdot \mathrm{s}^{-1}$ and the drainage area is $120.2 \mathrm{~km}^{2}$ (Povodí Vltavy 2009). The Teplá Vltava River has its main source at $1,172 \mathrm{~m}$ a.s.l. and represents the main source for the Vltava River. The river length is $54.9 \mathrm{~km}$, the drainage area $347.0 \mathrm{~km}^{2}$ and the mean discharge at the junction is $5.9 \mathrm{~m}^{3} \cdot \mathrm{s}^{-1}$ (Povodí Vltavy 2009). At the junction of the Studená and the Teplá Vltava Rivers, the Vltava River originates at $731 \mathrm{~m}$ a.s.l. in the peat bog locality Mrtvý luh. After reaching the Lipno Dam, the Vltava River discharges $8.7 \mathrm{~m}^{3} . \mathrm{s}^{-1}$ and the drainage area amounts to $515.1 \mathrm{~km}^{2}$ (Povodí Vltavy 2009). A left tributary of the Teplá Vltava River, the Volarský potok Brook, was studied as well. This brook springs at $900 \mathrm{~m}$ a.s.l. and its length reaches $10.5 \mathrm{~km}$ and drainage area $33.1 \mathrm{~km}^{2}$ (Vlček et al. 1984). The 


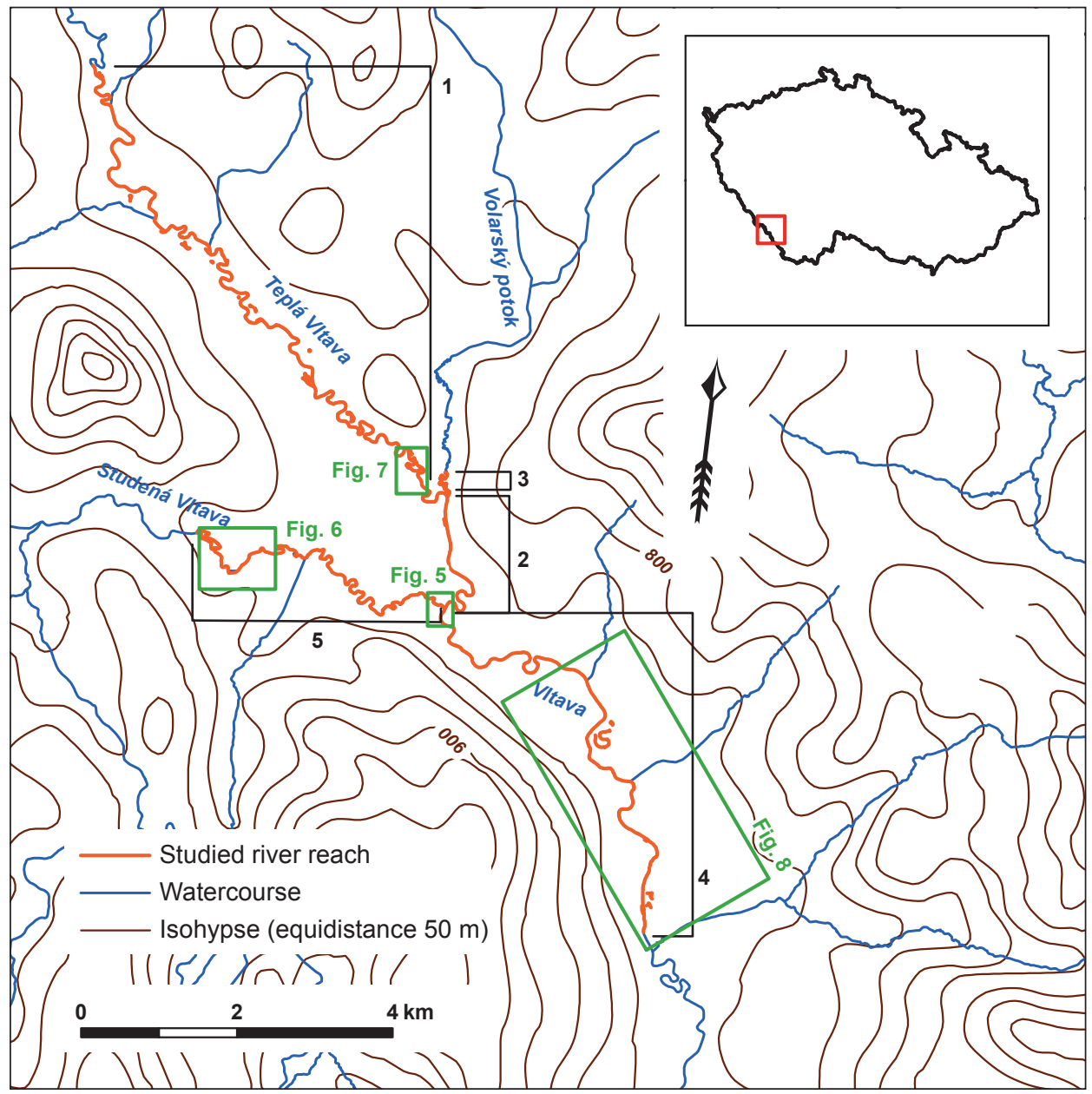

Fig. 2 - Study site in the Upper Vltava River basin. 1 and 2 - Teplá Vltava 1 and 2, 3- Volarský potok reach, 4 - Vltava reach, 5 - Studená Vltava reach.

study basin of the Upper Vltava River belongs to the cold climatic region $\mathrm{CH} 7$, marginally to the mild region MT3 (Quitt 1971). The mean annual air temperatures vary between 4 and $5{ }^{\circ} \mathrm{C}$ and the mean annual precipitation exceeds $700 \mathrm{~mm}$. In the headwaters source area, the precipitation amount reaches up to $1,400 \mathrm{~mm}$ (Tolasz et al. 2007).

Most of the examined floodplain area consists of floodplain sediments and quaternary peat. The bedrock is built of Palaeozoic granite and granodiorite and Palaeozoic to Proterozoic migmatite (Pelc 1996). The Upper Vltava River valley is entirely preserved as National Monument Vltavský luh Floodplain and is registered as the Ramsar site Šumavské rašeliniště peat bog. In addition, the protection of the Upper Vltava River and its headwaters is guaranteed by Ramsar convention and by the designation of Nature Monument Vltavský luh Floodplain. The riparian vegetation consists predominantly of peat bogs and 
meadows with an insignificant anthropogenic impact. The river banks of the Vltava reach (number 4 in Figure 2) are also to a limited extend covered by the coniferous forest. This reach was affected by channel alterations (Sádlo, Bufková 2002).

The runoff regime significantly differs from the regime in the Upper Jizera River basin as shown in Table 1 . The variability of runoff regime in the studied area is predominantly influenced by thawing periods during winter or early spring; the less significant peak of runoff occurs during summer (Povodí Vltavy 2009). Floods in August 2002 and March 2002 and 2008 are reported as the most significant events in this basin. Diurnal precipitation amount exceeded 100 mm in 2002 (Sandev, Květoň, Jovanovič 2003).

\section{Material and methods}

Although historical maps from the $19^{\text {th }}$ century can provide valuable information about the natural status of landscape in past time periods (e.g. Hooke, Redmond 1989), they were not used in order to study channel changes. The main reason for this decision is low accuracy characterised by root mean square reaching up to $50 \mathrm{~m}$ in some parts of Czechia (Zimova, Peštak, Veverka 2006), long-term map creation and the style of cartographic presentation. For the Upper Jizera River basin, six orthophotomaps from 1938 were used. For Upper Vltava River, three orthophotomaps from 1952 were obtained. Since the collecting of orthophotomaps for national purposes usually occupies several years and the process of the data assembly was interrupted in 1938, the orthophotomaps for the Vltava River basin were available only after the World War II. However, the measured lateral erosion rate is expressed in units independent of the selected time period. These monochromatic aerial photographs were scanned to TIFF format at resolution of 1,800 DPI; one pixel is an equivalent to $22 \mathrm{~cm}$ (Military Geography and Hydrometeorology Office 2012). The aerial photographs obtained in 1938 were taken in approximate scale of 1:15,700, whereas those taken in $1952 \mathrm{had}$ an approximate scale of 1:23,000 (Military Geography, Hydrometeorology Office 2012).

The historical aerial photographs were referenced using suitable control points (i.e. buildings and crossroads) identified on the historical aerial photographs and on the orthophotomap of Czechia from 2012 (Czech Environmental Information Agency 2012). In order to obtain higher accuracy of transformation, control points were preferentially placed close to the studied channel (sensu Pišút 2006). Georeferencing of the orthophotomaps was thus only local, but sufficient enough for the purpose of this paper. Root mean square errors of the registered photographs for the horizontal direction are quite low, as shown in Table 2 and 3.

The river banks were subsequently delineated at the scale of 1:2,000 in ArcGIS 10 software by editing tools. Double line presentation of the edited data was changed to a river axis by ArcGIS tool Collapse Dual Lines To Centerline. This river axis was created in order to make the measuring of the river reaches more accurate and to improve the data comparing in the required time periods. The selected rivers were divided into reaches in accordance to 
Tab. 2 - Errors determined during georeferencing the orthophotomap from 1938

\begin{tabular}{|lcc|}
\hline Orthophoto & RMS (pix) & RMS (m) \\
\hline 1 & 4.76 & 1.05 \\
2 & 0.30 & 0.07 \\
3 & 3.52 & 0.77 \\
4 & 1.04 & 0.23 \\
5 & 1.10 & 0.24 \\
6 & 3.44 & 0.76 \\
Mean & 2.36 & 0.52 \\
\hline
\end{tabular}

Tab. 3 - Errors determined during georeferencing the orthophotomap from 1952

\begin{tabular}{|lcc|}
\hline Orthophoto & RMS (pix) & RMS (m) \\
\hline 1 & 3.60 & 0.79 \\
2 & 0.65 & 0.14 \\
3 & 0.43 & 0.10 \\
Mean & 1.56 & 0.34 \\
\hline
\end{tabular}

sinuosity. Channel sinuosity is defined as the degree to which a river channel diverges from a straight line (Ebisemiju 1994). Although a variety of channel sinuosity indexes was suggested, it was determined in this paper as the ratio of the channel reach length (i.e. centreline) to the length of the shortest line connecting the end points. The comparison of the channel lengths between the orthophotographs was then made for each river reach. The maximum annual lateral erosion rates $\left(m\right.$. year $\left.^{-1}\right)$ were subsequently calculated for the Upper Vltava River basin (60-year period) and the Upper Jizera River basin (74-year period) for each river reach. The lateral erosion change (bank line movement) can be simply calculated by measuring the maximum (or mean) differences of the river bank lines (Hooke 1980). However, other techniques have been published as well. Sundberg (1956) measured the areas of lateral erosion and Brice (1973) delineated the vectors of movement of single points.

In some localities, accurate river bank mapping was constrained by dense vegetation. However, in comparison to historical topographic maps, aerial photographs commonly include much more accurate information about bank line course. In addition, the definition of river banks is more accurate in comparison to those for braided gravel bed rivers (Winterbottom 2000).

\section{Results}

4.1. Horizontal channel development in the Upper Jizera River basin

Since 1938, the Upper Jizera River and the Jizerka River have experienced changes varying in accordance to channel patterns, especially sinuosity. The examined rivers contain seven separate river courses. The Upper Jizera River was divided into four reaches based on sinuosity (Fig. 1): (1) source course 
Tab. 4 - Comparison of selected river reaches in the Upper Jizera River area basin between 1938 and 2012

\begin{tabular}{|lccccc|}
\hline River course & $\begin{array}{c}\text { Length } \\
1938(\mathrm{~km})\end{array}$ & $\begin{array}{c}\text { Length } \\
\text { 2012 }(\mathrm{km})\end{array}$ & $\begin{array}{c}\text { Change }(\%) \\
\text { Sinuosity } \\
1938\end{array}$ & $\begin{array}{c}\text { Sinuosity } \\
2012\end{array}$ \\
\hline Jizera 1 & 4.36 & 4.49 & 2.98 & 1.83 & 1.89 \\
Jizera 2 & 4.03 & 4.36 & 8.19 & 2.00 & 2.17 \\
Jizera 3 & 1.56 & 1.56 & 0.00 & 1.14 & 1.15 \\
Jizera 4 & 3.82 & 3.87 & 1.31 & 1.34 & 1.37 \\
Jizera 1-4 & 13.77 & 14.28 & 3.70 & 1.57 & 1.65 \\
Jizerka 1 & 2.79 & 2.80 & 0.36 & 1.41 & 1.40 \\
Jizerka 2 & 2.54 & 2.58 & 1.57 & 1.58 & 1.61 \\
Jizerka 3 & 2.38 & 2.39 & 0.42 & 1.25 & 1.25 \\
Jizerka 1-3 & 7.71 & 7.77 & 0.78 & 1.43 & 1.44 \\
\hline
\end{tabular}

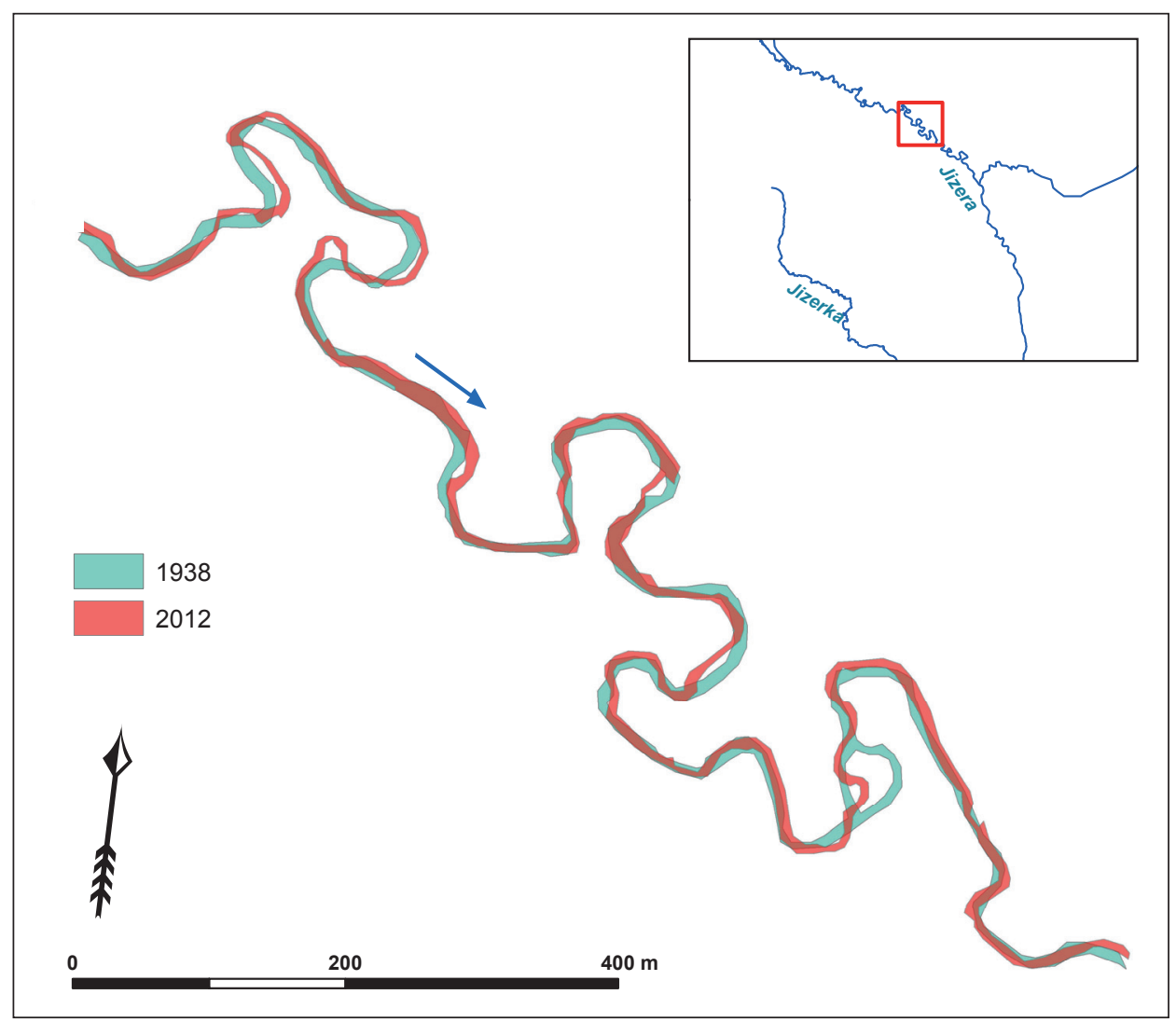

Fig. 3 - Locality with the most significant horizontal changes on the Upper Jizera River

characterised mainly by river bends, (2) free meandering river course with the highest rate of sinuosity, (3) incising river reach with the lowest rate of sinuosity, and (4) deeply incised course with sinuosity higher than in previous reach. The Jizerka River was separated into three reaches according to sinuosity 


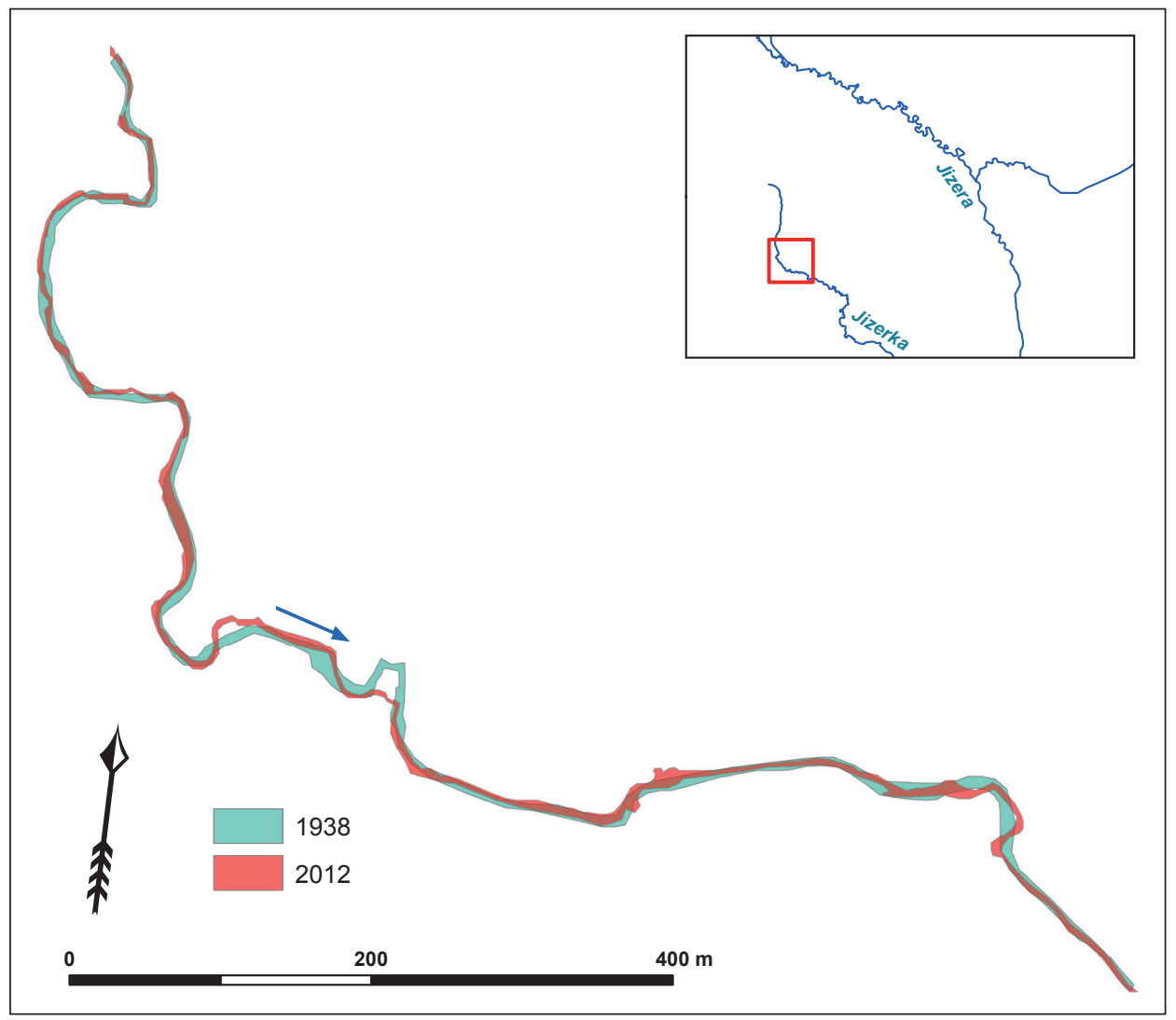

Fig. 4 - Locality with the most significant horizontal changes on the Jizerka River

(Fig. 1): (1) source course including bends only, (2) free meandering course with the highest rate of sinuosity, and (3) incised reach with a low rate of sinuosity.

As shown in Table 4, the length of the particular river courses has increased or, in one occurrence, has remained approximately constant. In addition, the noted increasing change in the river length is generally in relation to significantly increasing sinuosity. The highest lateral channel change was on the Upper Jizera River (Jizera 3 reach, Fig. 3), reaching 38.3 m (Fig. 3 and Table 6). What is clearly visible is the disappearance of one river branch. On the Jizerka River, the maximum channel displacement reached $25.7 \mathrm{~m}$ in the Jizerka 2 reach (Fig. 4), where one cut-off of a small extent is developed. Thus, the maximal lateral erosion rate is 0.52 m.year ${ }^{-1}$ for the Upper Jizera River and 0.35 m.year ${ }^{-1}$ for the Jizerka River (Table 6). It can be assumed that the lateral erosion predominates over the river incision on the reaches with the highest rates of the lateral erosion (Jizera 2, Jizerka 2, see Fig. 1 and Kasprzak, Traczyk 2011) and on the headwater reaches (Jizera 1 and Jizerka 1). On the contrary, river incision is characteristic of the reaches Jizera 3 and 4, which have the low rates of lateral erosion. The Jizerka 3 reach is dominated by river incision mainly due to the higher erosional efficiency of the Jizera River. The channel morphology 
is characterized mainly by the crescent-shaped point bars occurring especially in the meandering course of the Upper Jizera River (the Jizera 2 reach). Mid-channel bars are not abundant. The Jizerka River course does not contain visible point bars or side bars. The extent of the largest point bar was $1,453 \mathrm{~m}^{2}$.

\subsection{Horizontal channel development in the Upper Vltava River basin}

Five river reaches in the Upper Vltava River basin were classified according to channel sinuosity (Fig. 2). Two reaches were determined for the Teplá Vltava River and one reach was determined for the Studená Vltava River, the Vltava River and the Volarský potok Brook.

Three river reaches elongated and two reaches shortened during the studied period (Table 5). The Studená Vltava reach experienced the most significant change in the length. However, the highest sinuosity was recorded in the Volarský potok Brook reach. The highest absolute channel change of $67.4 \mathrm{~m}$ was identified in the lower part of the Studená Vltava reach (Table 6, Fig. 5). The lowest rate of channel change, $4.9 \mathrm{~m}$, was on the Volarský potok Brook. The annual lateral erosion rate ranged from $0.08 \mathrm{~m}$ on the Volarský potok Brook to $1.12 \mathrm{~m}$ on the Studená Vltava River. Locality on the Studená Vltava reach is the most significant example of river cut-off within both studied sites (Fig. 5). In the upper part of the Studená Vltava reach, there is a location with significant changes as well. What is especially significant is the double branching in comparison to the situation in 1952 (Fig. 6) as well as on the Teplá Vltava 1 reach (Fig. 7). The lateral erosion generally predominates over the river incision on

Tab. 5 - Comparison of selected river reaches in the Upper Vltava River area basin between 1952 and 2012

\begin{tabular}{|lccccc|}
\hline River course & $\begin{array}{c}\text { Length } \\
1952(\mathrm{~km})\end{array}$ & $\begin{array}{c}\text { Length } \\
2012(\mathrm{~km})\end{array}$ & Change (\%) & $\begin{array}{c}\text { Sinuosity } \\
1952\end{array}$ & $\begin{array}{c}\text { Sinuosity } \\
2012\end{array}$ \\
\hline Studená Vltava & 5.72 & 6.14 & 7.29 & 1.78 & 1.90 \\
Volarský potok & 0.75 & 0.76 & 1.95 & 2.27 & 2.47 \\
Teplá Vltava 1 & 13.19 & 13.44 & 1.97 & 1.84 & 1.88 \\
Teplá Vltava 2 & 2.27 & 2.26 & -0.25 & 1.58 & 1.58 \\
Vltava & 7.57 & 7.49 & -1.06 & 1.55 & 1.54 \\
\hline
\end{tabular}

Tab. 6 - Maximal horizontal channel change and maximum annual lateral erosion rate on studied reaches

\begin{tabular}{|lcc|}
\hline River & Maximal channel change $(\mathrm{m})$ & Maximal erosion rate $\left(\mathrm{m} . \mathrm{a}^{-1}\right)$ \\
\hline Jizera & 38.30 & 0.49 \\
Jizerka & 25.70 & 0.35 \\
Teplá Vltava & 19.90 & 0.33 \\
Studená Vltava & 67.40 & 1.12 \\
Vltava & 21.20 & 0.35 \\
Volarský potok & 4.90 & 0.08 \\
\hline
\end{tabular}




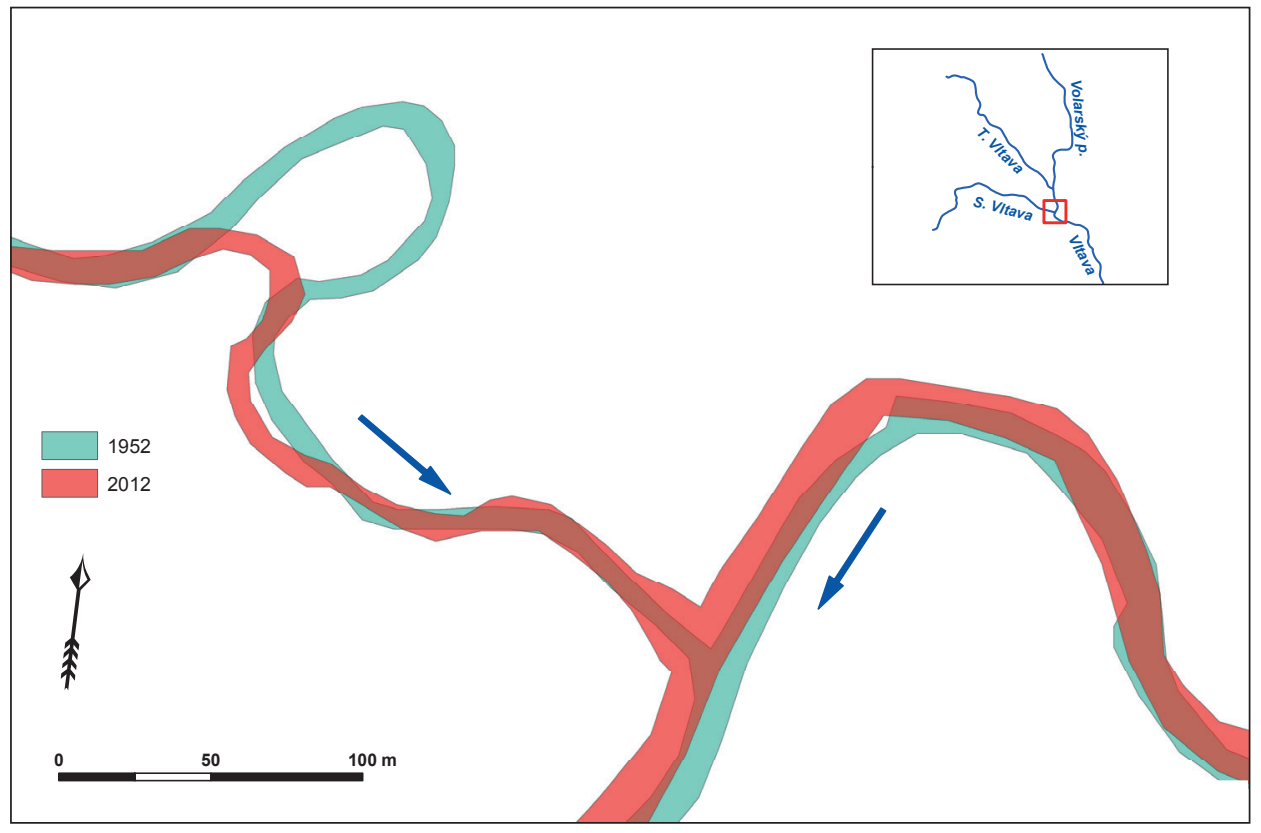

Fig. 5 - Locality with the most significant changes at the junction of the Studená and Teplá Vltava Rivers

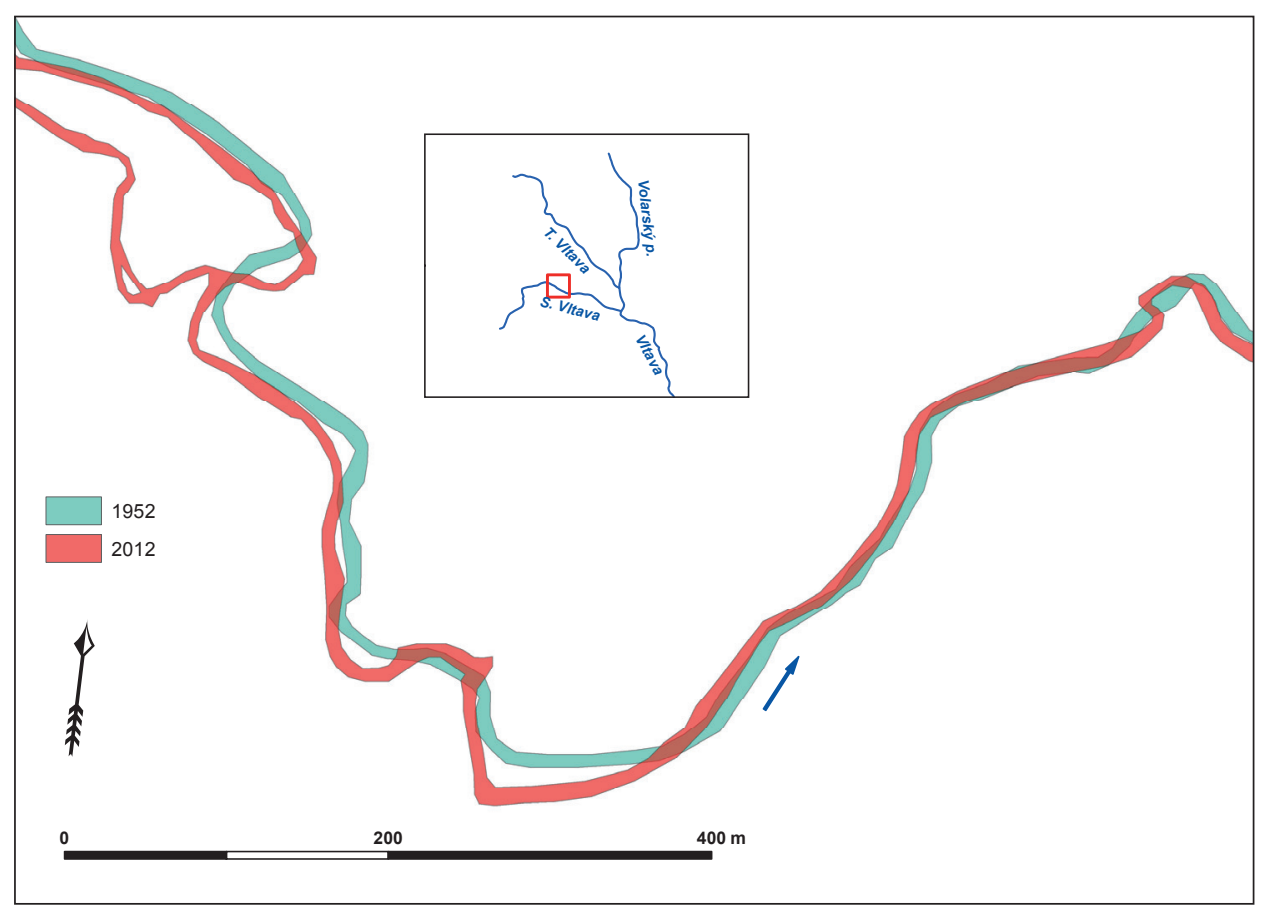

Fig. 6 - Locality with the most significant changes on the Studená Vltava River 


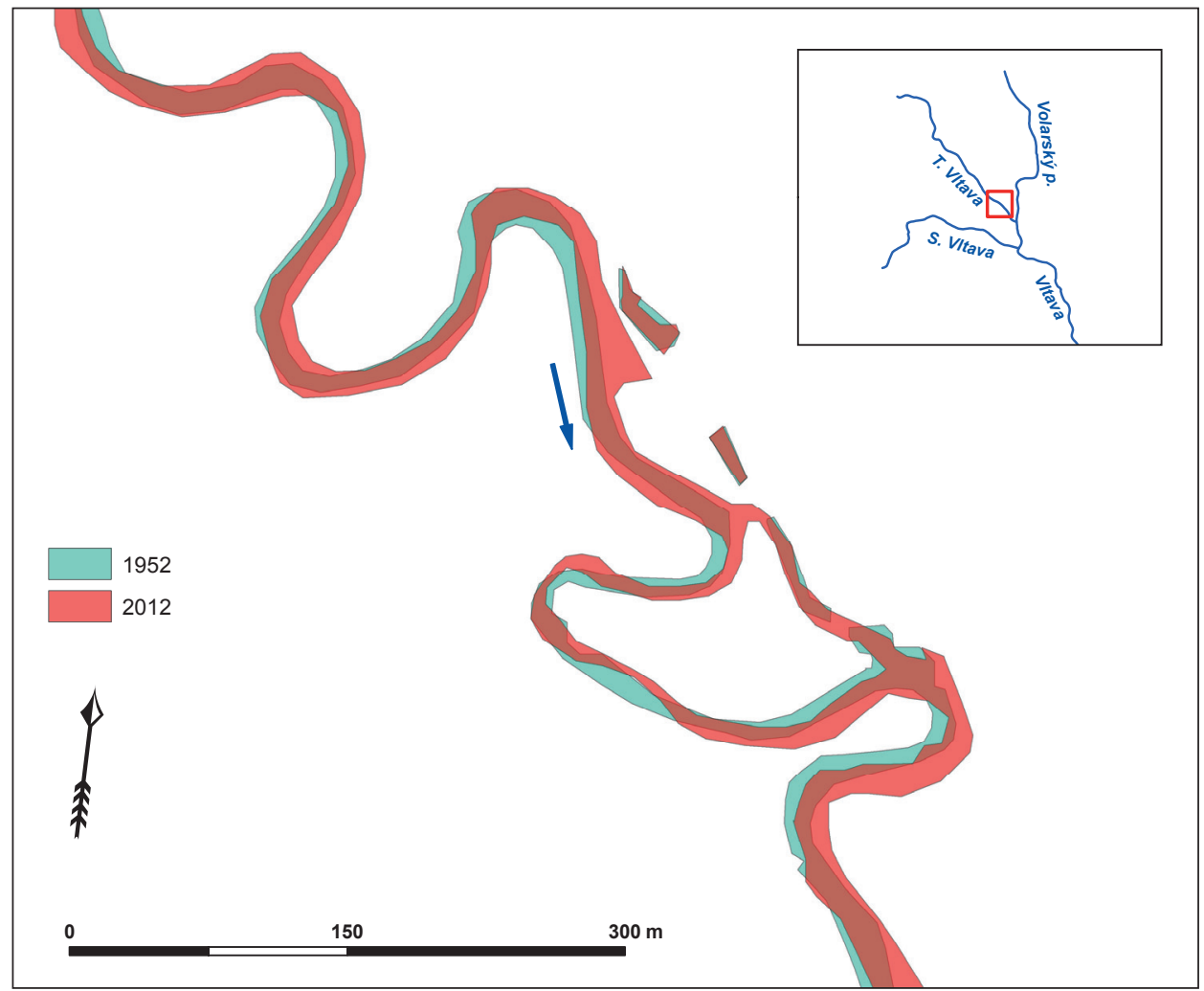

Fig. 7 - Locality with the most significant changes on the Teplá Vltava River

all the studied reaches. The river courses which have experienced shrinkage in the length have the lowest rate of sinuosity (see Table 5). The lowest sinuosity was measured on the Vltava River. Volarský potok Brook reaches the highest sinuosity of the studied river courses. There is a small number of visible bars in the Vltava River locality. Several significant point bars and mid-channel bars are developed in the Studená Vltava channel. The largest point bar covers the area of $405 \mathrm{~m}^{2}$. On the other river courses, there is almost no evidence about either point bars or mid-channel bars.

\section{Discussion}

The channel change investigation in the selected basins present similar results and have not shown any exceptional rates in comparison with other European rivers. Only the Volarský potok Brook has exceptionally low rates of the lateral erosion probably due to small fluvial dynamics within the examined reach. The more significant rates of the lateral erosion in the Studená Vltava reach may be caused by the higher number of the flood events in comparison with the Upper Jizera River basin. Thus, even the branching on the Studená 
Vltava River originating during the studied period may be caused by higher frequency of channel forming discharges. In addition, the frequency of minimally 5 -year recurrence floods has significantly increased during the last ten years in especially this locality (see Table 1). This tendency will supposedly further intensify the fluvial dynamics and the rates of lateral erosion. Nevertheless, the local geomorphological, geological and pedological settings and their variability may play a significant role as well.

Kasprzak and Traczyk (2011) presented an important channel change investigation from the Upper Jizera River and its tributaries in the period of 1953-2007. The maximum channel displacement was assumed in the locality of the Jagnięcy potok Brook and the Upper Jizera River, reaching identically $25 \mathrm{~m}$. The measured values correspond to the annual lateral erosion rate of $0.46 \mathrm{~m}$. These results are thus comparable to the values presented in this paper. Unfortunately, the basin of the Jagnięcy potok Brook, where Kasprzak and Traczyk (2011) supposed the highest lateral erosion rate, was not covered by any orthophotomap from 1938. Similar values were determined on the upper Bóbr River and its tributaries, south-western Poland, located closely to the Upper Jizera River (Teisseyre 1990). Kasprzak and Traczyk (2011) assume that river bank stabilisation on the Upper Jizera River and the Jagnięcy potok Brook is influenced by well consolidated peat covering. The enhanced cohesion on river banks containing higher proportion of organic matter was observed also in older studies (e.g. Wolfert, Maas 2007). Thus, the lateral erosion rates reach rather insignificant values in the studied basins.

The average annual lateral erosion on the Tichá Orlice River, Czechia, was estimated to $0.12-2.49 \mathrm{~m}$ in the time period of 1850-2001 (Skalická 2008). The maximum rate of lateral in this basin amounts to 3.47 m.year ${ }^{-1}$ (Skalická 2008). The maximum channel displacement on the Morávka River was estimated to $340 \mathrm{~m}$ in 1836-2009 and the lateral erosion rate thus reached 1.97 m.year ${ }^{-1}$ (Trnčák 2012). However, the Morávka River course was significantly affected in the last two centuries by anthropogenic impacts, especially by channel straightening and water reservoirs construction. Additionally, the channel changes of both the Tichá Orlice and the Morávka Rivers were assessed using the historical maps with generally low accuracy. Moreover, the above mentioned exceptional valley morphology may determine the rather low rates of lateral erosion.

The changes of the meandering Vecht River, the Netherlands, were studied within the pre-channelisation period (Wolfert, Maas 2007). The estimated mean lateral erosion rates amounted to 0.46 m.year ${ }^{-1}$ for the period of $1720-1850$ and 0.55 m.year ${ }^{-1}$ for the period of $1850-1890$. The river banks in the examined locality have a higher content of organic matter and their lateral erosion was examined in period with low anthropogenic impact. Thus, the lateral erosion rates together with the pedological setting and the anthropogenic impact are comparable with the basins examined in this paper. In the Danube River drainage basin, the changes on the Hernád River, Hungary, were examined. The rather higher rates of the average lateral erosion during the period of 1953-2002 (1.8-2.8 m.year $\left.{ }^{-1}\right)$ might have been caused by the enhanced human impact and the consequent increasing frequency of rapid floods (Kiss, Blanka 2012). On the British Isles, where rivers are often 


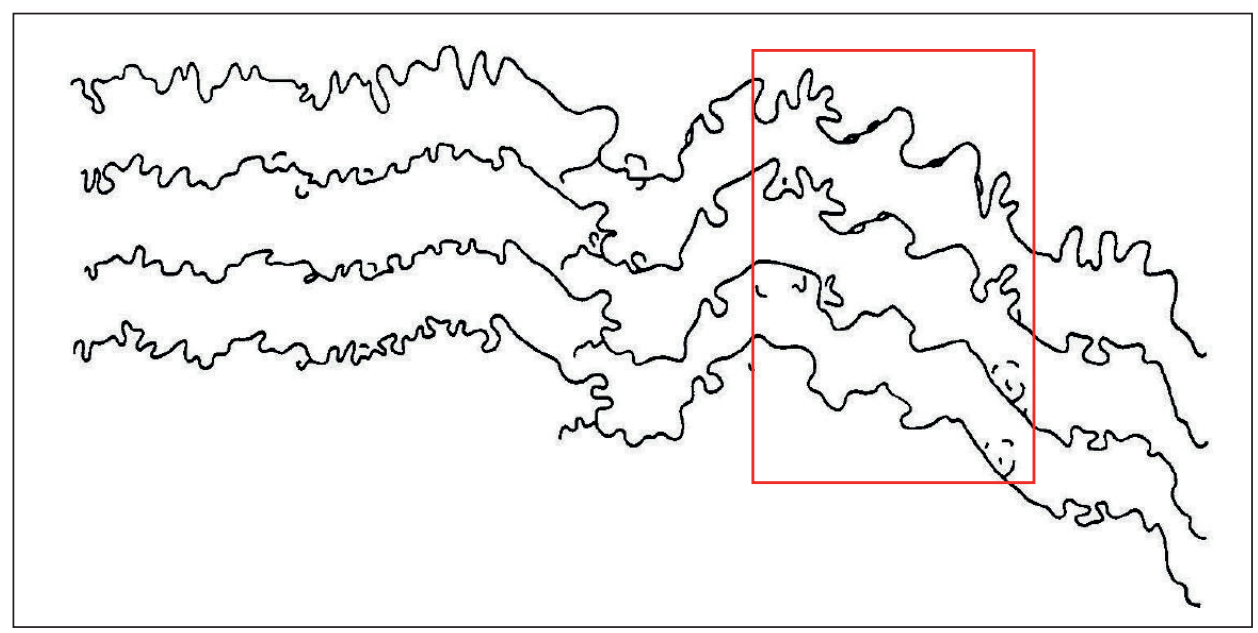

Fig. 8 - Meandering Teplá Vltava River and Vltava River: a) second half of the $18^{\text {th }}$ century, b) second half of the $19^{\text {th }}$ century, c) second half of the $20^{\text {th }}$ century, d) recent condition (1999). Location with presumably anthropogenic impact is marked. After Sádlo, Bufková (2002).

located in similar geomorphologic conditions as the Upper Jizera and the Upper Vltava Rivers, the annual lateral erosion reaches higher rates. On the Dane River, north-west England, the average rates on the most active bends and meanders reach the values of $0.5-1.0 \mathrm{~m}^{-y_{e a r}{ }^{-1}}$ and the maximum lateral erosion rates reach up to 3 m.year ${ }^{-1}$ (Hooke 2007). During much shorter periods (1970-1988), the maximum lateral erosion rates on the Dane and the Bollin Rivers ranged from 1.25 to 2.19 m.year ${ }^{-1}$ (Hooke 1995). Nevertheless, significantly different vegetation cover on the British Isles must be taken into consideration when comparing the lateral erosion rates with those in Czechia. What is characteristic of the drainage areas on the British Isles is the insignificant forest coverage rate. This fact results in a higher rate of surface runoff and consequent extreme flood events which strongly influence the channel change.

Theoretically, it is assumed that a river reach maintains its length and sinuosity constant even if bends exhibit growth or cut-off (Hooke 1984). However, rivers as dynamic fluvial systems respond to a complex system of both natural and anthropogenic factors and usually exhibit distinct changes in length and sinuosity. The decrease in sinuosity is usually attributed to anthropogenic factors such as deforestation and urbanisation. In the Upper Jizera and the Upper Vltava River study sites, almost all the investigated river reaches in both the study sites enlarged the sinuosity during the studied periods. As shown in Table 4 and 5, the river reaches with the highest sinuosity exhibited both the largest prolongation and the maximum channel displacement. Within the examined basin, only two river reaches (Teplá Vltava 2 and Vltava) underwent shortening (see Table 5). The Vltava reach with the most distinctive shortening was presumably straightened during the $19^{\text {th }}$ century (Fig. 8), as presented by Sádlo and Bufková (2002). Consequently, the incised river reach disabled further meandering development. 
Anthropogenic factors were significantly reduced during the last 70 years, when the landscape in both the borderline basins was abandoned by human (Matyáš, Kučera 2004). However, forest degradation and deforestation in the Upper Jizera River basin during the 1970s and 1980s caused destabilisation of the river banks (Kasprzak, Traczyk 2011). Thus, the consequent enhanced amount of sediment supply might have even accelerated the river channel change (Warburton, Danks, Wishart 2002). It is assumed that several large flood episodes occurring during the studied time period have crucially affected the channel change in both the study sites, when the lateral erosion is significantly enhanced (Kasprzak, Traczyk 2011; Sádlo, Bufková 2002). Moreover, thermoabrasion is another factor contributing to the modification of river channels. According to Teisseyre (1990), thermoabrasion is responsible for more than $60 \%$ of bank displacement in the Sudeten mountains. This process is probably very effective in the Upper Jizera River basin due to the frequent thermal inversions that occur even during summer season (Sobik, Błaś 2010; Kasprzak, Traczyk 2011). In the Upper Vltava River basin with analogous geomorphologic and climatic (Bufková, Rydlo 2008) conditions, thermoabrasion is probably an important geomorphological factor of the river channel evolution as well. Moreover, Wolman (1959) suggested that the lateral erosion is more effective during winter months, when the wetter river banks are more susceptible to erosion. This factor may be crucial predominantly in the Upper Vltava River basin characterised by floods occurring predominantly in winter or early spring.

\section{Conclusions}

Both the selected basins, characterised by similar geomorphologic and microclimatic conditions, exhibit analogous rates of the maximum lateral erosion, reaching prevailingly $0.3-0.5$ m.year ${ }^{-1}$. Calculated lateral erosion rates correspond with observations from Kasprzak and Traczyk (2011) and validated the hypothesis stated by author. Nevertheless, especially some parts of the Studená Vltava River reached more than double rate of lateral erosion, as compared to other studied river reaches. This situation may be caused by the higher frequency of channel forming events in this area which occur predominantly during winter and may thus enhance the erosional effect. The local variability of geological, geomorphological and pedological setting may play an important role as well. The river reaches with high rates of sinuosity underwent the most significant prolongation, whereas the length of the river reaches with low sinuosity stagnated or shortened. The analysis and quantification of the selected rivers through the use of the historical orthophotomaps identified generally insignificant changes in comparison to other rivers in Central Europe or on the British Isles. The generally small changes in the examined basins are presumably caused by high organic content in the river banks and insignificant anthropogenic impact in the examined areas. It must be emphasised that the aforesaid annual lateral erosion rates are just estimated as the channel-forming discharges during several floods constitute the main contribution to the erosional processes and the process of lateral erosion is thus not continuous. Furthermore, the accuracy of georeferencing should be taken into account 
during the assessing of the lateral erosion rates. A small anthropogenic impact in the studied basins is crucial for further investigation and understanding to fluvial systems within the area of Central Europe.

\section{References:}

ANDREOLI, A., COMITI, F., LENZI, M.A. (2007): Characteristics, distribution and geomorphic role of large woody debris in a mountain stream of the Chilean Andes. Earth Surface Processes and Landforms, 32, No. 11, pp. 1675-1692.

BRICE, J.C. (1973): Meandering pattern of the White River in Indiana - an analysis. In: Morisawa, M. (ed.): Fluvial Geomorphology. State University of New York, Binghamton, pp. $179-200$.

BROOKS, A.P., BRIERLEY, G.J., MILLAR, R.G. (2003): The long-term control of vegetation and woody debris on channel and flood-plain evolution: Insights from a paired catchment study in southeastern Australia. Geomorphology, 51, No. 1-3, pp. 7-29.

BUBENÍČKOVÁ, L., KULASOVÁ, A. (2009): Podnebí a počasí Jizerských hor. In: Karpaš, R. (ed.): Jizerské hory. O mapách, kamení a vodě. Nakladatelství RK, Liberec, pp. 342-383.

BUFKOVÁ, I., RYDLO, J. (2008): Vodní makrofyta a mokřadní vegetace odstavených říčních ramen horní Vltavy (Hornovltavský luh, NP Šumava). Silva Gabreta, 14, No. 2, pp. 93-134.

DANHELKA, J., ČEKAL, R., ČERNÁ, J., ELLEDER, L., RYGLEWICZ, M., SKALÁK, P. (2006): Roční zpráva o hydrometeorologické situaci v České republice, ČHMÚ, Praha, $35 \mathrm{pp}$.

DUAN, J.G., JULIEN, P.Y. (2010): Numerical simulation of meandering evolution. Journal of Hydrology, 391, No. 1-2, pp. 34-46.

DULAL, K.P., SHIMIZU, Y. (2010): Experimental simulation of meandering in clay mixed sediments. Journal of Hydro-environmant Research, 4, No. 4, pp. 329-343.

EBISEMIJU, F.S. (1994): The Sinuosity of Alluvial River Channels in the Seasonally Wet Tropical Environment: Case Study of River Elemi, Southwestern Nigeria. Catena, 21, No. 1 , pp. 13-25.

FROTHINGHAM, K.M., RHOADS, B.L. (2003): Three-dimensional flow structure and channel change in an asymmetrical compound meander loop, Embarras River, Illinois. Earth Surface Processes and Landforms, 28, No. 6, pp. 625-644.

FULLER, I.C. (2008): Geomorphic impacts of a 100-year flood: Kiwitea Stream, Manawatu catchment, New Zealand. Geomorphology, 98, No. 1-2, pp. 84-95.

GURNELL, A.M. (1997): Channel change on the River Dee meanders, 1946-1992, from the analysis of air photographs. Regulated Rivers: Research and Management, 13, No. 1, pp. 13-26.

GURNELL, A.M., DOWNWARD, S.R., JONES, R. (1994): Channel planform change on the River Dee meanders, 1876-1992. Regulated Rivers: Research and Management, 9, No. 4, pp. 187-204.

HOOKE, J. M. (1980): Magnitude and distribution of rates of river bank erosion. Earth Surface Processes, 5, No. 2, pp. 143-157.

HOOKE, J.M. (1984): Changes in river meanders: a review of techniques and results of analyses. Progress in Physical Geography, 8, No. 4, pp. 473-508.

HOOKE, J.M. (1995): River channel adjustment to meander cutoffs on the River Bollin and River Dane, northwest England. Geomorphology, 14, No. 3, pp. 235-253.

HOOKE, J.M. (2007): Spatial variability, mechanisms and propagation of change in an active meandering river. Geomorphology, 84, No. 3-4, pp. 277-296.

HOOKE, J.M., REDMOND, C.E. (1989): Use of Cartographic Sources for Analysing River Channel Change with Examples from Britain. In: Petts, G.E., Moller, H., Roux, A.L. (eds): Historical Change of Large Alluvial Rivers: Western Europe. Chichester, Eley, pp. 79-93.

KAIL, J. (2003): Influence of large woody debris on the morphology of six central European streams. Geomorphology, 51, No. 1-3, pp. 207-223. 
KASPRZAK, M., TRACZYK, A. (2011): Rzeźba i rozwój doliny Izery w Sudetach Zachodnich. Opera Corcontica, 48, pp. 7-34.

KISS, T., BLANKA, V. (2012): River channel response to climate- and human-induced hydrological changes: Case study on the meandering Hernád River, Hungary. Geomorphology, $175-176$, pp. 115-125.

KLIMENT, Z., MATOUŠKOVÁ, M., ŠOBR, M., POTƯČKOVÁ, M., HUJSLOVÁ, J. (2008): Fluvial dynamics and selected methods of ecohydrological monitoring of restored Sviňovický brook channel. AUC-Geographica, 43, No. 1-2, pp. 125-144.

LANGHAMMER, J., MATOUŚKOVÁ, M. (2006): Mapping and analysis of river network modification as a factor of flood risk in the Blanice river basin. Geografie, 111, No. 3, pp. 274-291.

LANGHAMMER, J., VAJSKEBR, V. (2007): Využití GIS pro analýzu zkrácení říční sítě na základě historických mapových podkladů. In: Langhammer, J. (ed.): Povodně a změny v krajině. MŽP, PřF UK, Praha, pp. 153-168.

LANGHAMMER, J., VILÍMEK, V. (2008): Landscape changes as a factor affecting the course and consequences of extreme floods in the Otava river basin, Czech Republic. Environmental Monitoring and Assessment, 144, No. 1-3, pp. 53-66.

LEHOTSKÝ, M., NOVOTNÝ, J., SZMAŃDA, J.B. (2010): Response of the Danube River floodplain to flood events during 2002-2007 period. Quaestiones Geographicae, 29, No. 3, pp. 37-45.

LI, L. Q., LU, X. X., CHEN, Z. (2007): River Channel Change during the Last 50 Years in the Middle Yangtze River: An Example of the Jianli Reach, Geomorphology, 85, No. 3-4, pp. 185-196.

LUCHI, R., HOOKE, J.M., ZOLEZZI, G., BERTOLDI, W. (2010): Width variations and mid-channel bar inception in meanders: River Bollin (UK). Geomorphology, 119, No. 1-2, pp. 1-8.

MAGILLIGAN, F.J. (1992): Thresholds and the spatial variability of flood power during extreme floods. Geomorphology, 5, No. 3-5, pp. 373-390.

MATYÁŠ, D., KUČERA, T. (2004): Opuštěné pohraničí - krajinný fenomén bývalých Sudet. Životné prostredie, 38, No. 6, pp. 320-324.

McEWEN, L.J., MATTHEWS, J.A. (1998): Channel form, bed material and sediment sources of the Sprongdøla, southern Norway: evidence for a distinct periglacio-fluvial system. Geografiska Annaler, 80 A, No. 1, pp. 17-36.

MŽP CR (2010): Vyhodnocení povodní v srpnu 2010. Vyhodnocení průběhu povodně ve vrcholových partiích Jizerských hor. MŽP ČR (Ministry of the Environment of the Czech Republic), http://voda.chmi.cz/pov10s/pdf/priloha3.pdf (5. 2. 2014).

OPRCHAL, J. (2009): Změny v průběhu koryta části toku řeky Svratky a jejich vliv na proces odtoku vody z povodí. Master thesis. Masarykova univerzita v Brně, Přírodovědecká fakulta, $98 \mathrm{pp}$.

PAVELKOVÁ CHMELOVÁ, R., NETOPIL, P. (2007): Historické letecké snímky v geografickém výzkumu - problémy při jejich zpracování a možná řešení. Miscellanea Geographica, 13, pp. 129-136.

PILOUS, V. (2008): Pramen Jizery - nekonečný příběh? Krkonoše - Jizerské hory, 41, No. 11, pp. $4-8$.

PISÚT, P. (2006): Evolution of meandering Lower Morava River (W Slovakia) during the first half of $20^{\text {th }}$ Century. Geomorphologia Slovaca, 6, No. 1, pp. 55-68.

Povodí Labe (2009): The Upper and Middle Elbe River Basin District Plan. Povodí Labe, Hradec Králové, 478 pp.

Povodí Vltavy (2009): The Upper Vltava River Basin District Plan. Povodí Vltavy, České Budějovice, $394 \mathrm{pp}$.

SÁDLO, J., BUFKOVÁ, I. (2002): Vegetace Vltavského luhu na Šumavě a problém reliktních praluk. Preslia, 74, No. 1, pp. 67-83.

SANDEV, M., KVĚTOŇ, V., JOVANOVIČ, P., eds. (2003): Meteorologické příčiny katastrofální povodně v srpnu 2002 a vyhodnocení extremity př́íinných srážek. ČHMÚ, Praha, 160 pp.

SCOTT, K.M., GRAVLEE JR., G.C. (1968): Flood surge on the Rubicon River, California hydrology, hydraulics, and boulder transport. Physiographic and Hydraulic Studies of 
Rivers. U.S. Geological Survey Professional Paper 422-M. United States Government Printing Office, Washington, 45 pp.

SKALICKÁ, J. (2008): Geomorfologické změny meandrujícího koryta Tiché Orlice v historické době. Master thesis. Masarykova univerzita v Brně, Přírodovědecká fakulta, Brno, $84 \mathrm{pp}$.

SOBIK, M., BŁAŚ, M. (2010): Wyjątkowe zdarzenia meteorologiczne. In: Migoń, P. (ed.), Wyjątkowe zdarzenia przyrodnicze na Dolnym Śląsku i ich skutki. Rozprawy Naukowe Instytutu Geografii i Rozwoju Regionalnego, 14, Uniwersytet Wrocławski, Wrocław, pp. 35-80.

SUNDBERG, A. (1956): The river Klaralven, a study of fluvial processes. Geografiska Annaler, 38, pp. 127-316.

SURIAN, N., RINALDI, M. (2003): Morphological response to river engineering and management in alluvial channels in Italy. Geomorphology, 50, No. 4, pp. 307-326.

ŠTEKL, J., BRÁZDIL, R., KAKOS, V., JEŽ, J., TOLASZ, R., SOKOL, Z. (2001): Extrémní denní srážkové úhrny na území ČR v období 1879-2000 a jejich synoptické příčiny. Národní klimatický program Česká republika, 31, Praha, 140 pp.

TEISSEYRE, A.K. (1990): Dynamika sudeckich rzek żwirodennych w zimnej połowie roku. Acta Universitatis Wratislaviensis 1056, Prace Instytutu Geograficznego, seria A IV, pp. 119-142.

TESAŘ, M., PACZOS, A. (2009): Vodní toky Jizerských hor. In: Karpaš, R. (ed.): Jizerské hory. O mapách, kamení a vodě. Nakladatelství RK, Liberec, pp. 386-403.

THORNE, C.R. (1991): Bank Erosion and Meander Migration of the Red and Mississippi Rivers, USA. Hydrology for the Water Management of Large River Basins (Proceedings of the Vienna Symposium), pp. 301-313.

TOLASZ, R., MÍKOVÁ, T., VALERIÁNOVÁ, A., VOŽENÍLEK, V. (2007): Atlas podnebí Česka. ČHMÚ, Praha, Univerzita Palackého v Olomouci, Olomouc, 255 pp.

TRNČÁK, L. (2012): Analýza změn krajinného pokryvu nivy Morávky. Studentská vědecká konference 2012. Vysoká škola báňská - Technická univerzita Ostrava, Hornicko-geologická fakulta, pp. 34-37.

VLCEK, V., KESTRÁNEK, J., KŘÍŽ, H., NOVOTNÝ, S., PÍŠE, J. (1984): Vodní toky a nádrže. Zeměpisný lexikon ČSR. Academia, Praha, 316 pp.

VRABEC, M., ELLEDER, L., KESSL, J. (2000): Roční zpráva o hydrometeorologické situaci v České republice, ČHMÚ, Praha, 34 pp.

VRŠOVSKÝ, V. (2013): Horní Jizera nový ramsarský mokřad. Časopis Krkonoše - Jizerské hory, 46, No. 2, pp. 30-31.

WARBURTON, J., DANKS, M., WISHART, D. (2002): Stability of an upland gravel-bed stream, Swinhope Burn, Northern England. Catena, 49, No. 4, pp. 309-329.

WINTERBOTTOM, S.J. (2000): Medium and short-term channel planform changes on the Rivers Tay and Tummel, Scotland. Geomorphology, 34, No. 3-4, pp. 195-208.

WOLFERT, H.P., MAAS, G.J. (2007): Downstream changes of meandering styles in the lower reaches of the River Vecht, the Netherlands. Geologie en Mijnbouw, 86, No. 3, pp. 257-271.

WOLMAN, M.G. (1959): Factors influencing erosion of a cohesive riverbank. Americal Journal of Science, 257, No. 3, pp. 204-216.

WOLMAN, M.G., MILLER, W.P. (1960): Magnitude and frequency of forces in geomorphic processes. Journal of Geology, 68, No. 1, pp. 54-74.

ZIMOVÁ, R., PEŠŤÁK, J., VEVERKA, B. (2006): Historical Military Mappings of the Czech Lands - Cartographic Analysis. Proceedings of the First International Conference on Cartography and GIS, Borovets, Bulgaria.

Data, maps, matherials:

Actual orthophotomaps. Ver. 1.3.0., Czech Environmental Information Agency Praha, GEODIS, Brno, 2012.

CHALOUPSKÝ, J. (1988): Geologická mapa ČR 1:50 000. List 03-14 Liberec. ÚÚG, Praha. CHALOUPSKÝ, J. (1989): Geologická mapa ČR 1:50 000. List 03-23 Harrachov. ÚÚG, Praha. ČHMÚ (2014): Flood forecasting service. ČHMÚ (Czech Hydrometeorological Institute), http:// hydro.chmi.cz/hpps/hpps_prfbk_detail.php?seq=307116 (4. 2. 2014). 
Orthophotomaps No. 1938_00172, 1938_00174, 1938_00201, 1938_00300, 1938_00302, 1938_09731, 1952_07084, 1952_07106 and 1952_07131. Military Geography and Hydrometeorology Office, Dobruška, 2012.

PELC, Z. (1996): Geologická mapa ČR 1:50 000. List 32-12 Volary. ČGS, Praha.

QUITT, E. (1971): Klimatické oblasti Československa. ČSAV, Brno, 73 pp. Supplement: Mapa klimatických oblastí ČSSR 1:500 000, Geografický ústav ČSAV, Brno.

Shrnutí

\section{HORIZONTÁLNÍ VÝVOJ KORYTA HORNÍ JIZERY A HORNÍ VLTAVY V LETECH 1938-2012}

Studie přináší doklady o aktivitě fluviálních procesů v oblasti horní Jizery a Vltavy a jejích přítoků. Vybrané toky představují v rámci střední Evropy geomorfologicky unikátní prostředí, které nebylo člověkem po druhé světové válce zásadně ovlivněno. Za účelem posouzení fluviální činnosti v dotčených lokalitách byly porovnány letecké snímky z roku 1938 (horní Jizera) a z roku 1952 (horní Vltava) se stavem z roku 2012. Toky byly podrobeny zejména analýze změny délky a sinuosity. Byl také zjištován maximální absolutní posun koryta a z něj vyplývající roční míra boční eroze. Na řece Jizeře a jejím levém přítoku, Jizerce, se v letech 1938-2012 délka jednotlivých úseků prodloužila. Výjimkou je pouze úsek č. 3 na řece Jizeře, jehož délka zůstala téměř totožná. Na řece Jizeře došlo k největšímu posunu koryta na úseku č. 2 , a to $38,3 \mathrm{~m}$. Roční míra boční eroze ve studovaném období činila maximálně 0,49 m.rok ${ }^{-1}$. $\mathrm{V}$ tomto úseku je také patrný zánik jednoho ramene vodního toku. Na řece Jizerce bylo koryto posunuto maximálně o $25,7 \mathrm{~m}$ v úseku č. 2 . Roční míra boční eroze v této lokalitě dosáhla 0,35 m.rok ${ }^{-1}$. V oblasti horní Vltavy došlo v periodě $1952-2012 \mathrm{k}$ prodloužení tří úseků, zatímco dva úseky se zkrátily. Uvedené zkrácené úseky se pravděpodobně nachází v území, které bylo nejvíce ovlivněno antropogenními pochody, a dosáhly nejmenší míry sinuosity. Nejvýraznější posun koryta se projevil na Studené Vltavě $(67,4 \mathrm{~m})$, na Teplé Vltavě a Vltavě dosahoval značně nižších hodnot (19,9 a 21,2 m). Nejmenší změna v poloze koryta nastala na Volarském potoce $(4,9 \mathrm{~m})$. Roční maximální míra eroze se pohybovala v rozmezí 0,08-1,12 m.rok ${ }^{-1}$. Na Teplé a Studené Vltavě jsou patrné dvě lokality, ve kterých došlo během studovaných 60 let k vzniku dalšího říčního ramene. Je pravděpodobné, že hlavním faktorem ovlivňujícím boční erozi jsou povodňové události, jejichž četnost se zejména v oblasti horní Vltavy zvyšuje. Navíc tuto oblast ovlivňují především zimní povodně, během nichž může být boční eroze v některých úsecích efektivnější. I přesto jsou roční hodnoty boční eroze v obou studovaných oblastech v rámci střední Evropy podprůměrné. Tato situace je pravděpodobně dána specifickou morfologií obou území, především nízkým sklonem toků, a vlastnostmi břehů, které jsou z velké části tvořeny organickým materiálem. Nízké hodnoty eroze mohou být také dány nízkým antropogenním tlakem. Tento článek zpřesňuje znalosti o fluviální aktivitě na vybraných tocích Česka.

Obr. 1 -Studovaná lokalita v oblasti povodí horní Jizery. 1-4 - úseky Jizera 1-4, 5-7 - úseky Jizerka 1-3 - Data pro Studenou Vltavu dle ĆHMÚ (2014), data pro Jizeru: Štekl a kol. (2001), Vrabec a kol. (2000), Daňhelka a kol. (2006).

Obr. 2 -Oblast povodí horní Vltava. 1 a 2 - úseky Teplá Vltava 1 a 2, 3 - úsek Volarský potok, 4 - úsek Vltava, 5 - úsek Studená Vltava.

Obr. 3 -Lokalita s největšími horizontálními změnami na toku horní Jizery.

Obr. 4 -Lokalita s největšími horizontálními změnami na toku Jizerky.

Obr. 5 - Lokalita s největšími horizontálními změnami na soutoku Studené a Teplé Vltavy.

Obr. 6 -Lokalita s největšími horizontálními změnami na Studené Vltavě.

Obr. 7 -Lokalita s největšími horizontálními změnami na Teplé Vltavě.

Obr. 8 - Meandrující Teplá Vltava a Vltava: a) druhá polovina 18. století, b) druhá polovina 19. století, c) druhá polovina 20. století, d) současný stav (1999). Vyznačená je oblast s předpokládaným antropogenním vlivem. Podle Sádla, Bufkové (2002). 
Author' affiliation: Charles University in Prague, Faculty of Science, Dpt. of Physical Geography and Geoecology, Albertov 6, 12843 Praha 2, Czechia; e-mail: hlozek2@natur.cuni.cz.

Initial submission, 27 May 2013; final acceptance 26 April 2014.

\section{Please cite this article as:}

HLOŽEK, M. (2014): Horizontal channel development on the upper Jizera and the upper Vltava Rivers between 1938 and 2012. Geografie, 119, No. 2, pp. 105-125. 